\title{
A Clash of Maritime Cultures: The US Navy vs. the Islamic Corsairs, 1783-1816
}

\section{William S. Dudley}

Le présent essai traite des origines de l'escadron méditerranéen de la Marine américaine et de son rôle à titre de nouvel instrument de la politique étrangère américaine. On y examine également les relations diplomatiques entre les régences islamiques de la côte de la Barbarie et les États-Unis, qui ont laissé présager certains événements futurs. Les deux pôles de ce récit sont le Traité de Paris de 1783 et les guerres américaines en mer méditerranéenne des années 1801 à 1816. Au cours de cette période, les États-Unis sont devenus une jeune nation maladroite qui évaluait les limites de l'autodétermination nationale par l'entremise du commerce et du recours à la puissance navale et militaire. Ainsi, les États-Unis se sont trouvés en situation de conflit avec les régences de la Barbarie, ce qui a donné lieu à des conséquences et à des résultats inattendus pour les deux parties. Ayant accepté l'argumentation de Grotius et Smith voulant que les mers soient libres pour le commerce, les Américains ont constaté que la mer Méditerranée était loin d'être libre.

With the rise of contemporary maritime terrorism, dating at least from the Achille Lauro incident in 1985, numerous writers have rediscovered the Barbary Wars of the early nineteenth century, seeking parallels with contemporary issues. ${ }^{1}$ Modern maritime terrorism refers to sub-state or non-state actors attacking commercial and naval ships for symbolic political purposes. There are, however, good historical reasons to examine the Barbary Coast conflicts as unique to their own time and place. This essay discusses the origins of the US Navy's Mediterranean Squadron

\footnotetext{
1 This work was presented during the annual national congress of the Naval Order of the United States, held in Honolulu, HI, on 19-22 October 2016. The author wishes to acknowledge the valuable assistance of Frederick C. Leiner, John B. Hattendorf and Edward Gabriel, US ambassador to Morocco (1997-2001) in the preparation of this paper.
}

The Northern Mariner/Le marin du nord, XXVII, No. 3 (July 2017), 229-244. 
and the part it played as the new instrument of American foreign policy. ${ }^{2}$ At the same time, it is important to examine diplomatic relations between the Barbary Coast Islamic regencies and the United States which were a foreshadowing of future events. The twin poles of this narrative are the final act of the American Revolution, the Treaty of Paris of 1783 and the United States' naval wars in the Mediterranean, 1801-1816. Between these dates, the United States grew from a republic that was barely capable of self-defense to an awkward young nation probing the limits of national self-determination through commerce and the use of naval and military power. In doing so, the United States found itself in conflict with the Barbary regencies whose seafarers had deep roots in the Mediterranean past, originating in the eighth century $\mathrm{AD}$, when Islamic seafarers emerged to challenge the fleets of Byzantium. ${ }^{3}$ This led to unexpected consequences and outcomes for both sides. The founders of the Republic, familiar with the writings of Hugo Grotius and Adam Smith, had acquired deep belief in the freedom of the seas as the best possible environment for America's neutral merchantmen, but they found that the Mediterranean Sea was anything but free.

These developments had their inception in the American Revolution. With the Treaty of Paris, the United States relinquished any claim she might have had to the protection of the British navy. American merchantmen venturing into the Mediterranean were forced to defend themselves, if possible, when attacked by pirates or the ships of an enemy state. It was not long before warships from Algiers on the Barbary Coast seized American merchant ships and their crews. The Algerines either converted these ships for their own use or sold them and held their crews hostage. This state of affairs festered during the years that the United States was forging its constitution and the essential institutions of national government, including military and naval forces. It was becoming all too clear that a maritime cultural crisis was in the making for the United States, particularly in the unaccustomed type of warfare and the treatment of prisoners that our sailors met in the Mediterranean.

For ten centuries before the French Revolution, the minor potentates of the Barbary regencies of Algiers, Tunis, and Tripoli, nominally client states of the Turkish sultanate, in addition to Morocco which was independent of the Ottoman Empire, had frequently depended on ship captures rather than commerce as their principal means of income. The immediate gains of their seizures were plunder,

\footnotetext{
${ }^{2}$ Invaluable for research on this period is the multi-volume documentary series edited by Captain Dudley W. Knox, Naval Documents related to the United States Wars with the Barbary Powers, 1785-1807, 6 vols. (Washington, DC: Government Printing Office, 1939-1944).

${ }^{3}$ Hassan S. Khalilieh, Admiralty and Maritime Laws in the Mediterranean Sea (ca. 800-1050):

The Kitab Akriyat al-Sufun vis-à-vis the Nomos Rhodion Nautikos (Leiden-Boston: Brill, 2006); Allen Fromherz, "Islam and the Sea," Oxford Islamic Studies Online (www.oxfordislamicstudies. com); Svat Souchek, "Islam and the Mediterranean Sea, 630-1500," in Oxford Encyclopedia of Maritime History $(O E M H), 4$ vols., edited by John B. Hattendorf (Oxford and New York: Oxford University Press, 2007), 2: 514-520.
} 
captives, and ships. The captives were treated and used as slaves until ransom could be negotiated with the subjects' governments. In attempting to forestall future captures and hostage taking, European governments commonly agreed to pay tribute in the form of money, supplies, and military and naval stores. In addition, cash gifts commonly accompanied new envoys to pave the way for smooth diplomatic relationships. By their willingness to suffer, reward, and manipulate the rapacious behaviour of the Barbary states, European nations encouraged it. There were times as in the mid- to late seventeenth century, when the Holland, England and France fought among themselves, this provided opportunities for expansion of corsair activity. Algiers was then the strongest seafaring regency. But even so Tripoli, viewed as having the least powerful fleet, sent out fifteen to twenty corsairs per year, ranging in size from small galleys to a 46-gun warship, The commanders of these vessels were often Turks or renegade (mostly Greek) Christians. Tripolitan cruising grounds were in the central Mediterranean, near the coasts of Italy and Greece. From 1680 to 1699 , as at the Battle of Lepanto over a century earlier, warfare between the Ottoman Turks and the Hapsburg Empire was fought on sea as well as on land. At such times, the Ottoman sultan called upon the regencies Algiers, Tunis and Tripoli to provide him with corsair warships, for which he paid. They would serve without pay but could keep any prizes and prisoners they captured. ${ }^{4}$

The predatory maritime practices of the Barbary regencies have traditionally been considered piracy by American and other historians, yet there is good reason to interpret their behaviour as more akin to privateering since they operated under the orders of the Islamic regency chieftains in their warfaring practices. Their owners and ship captains were obliged to pay a portion of their plunder to their overlord and to hand over captured ship crews and passengers to his control as well. They thus operated within a legal framework. Even though many privately owned their ships, they had to receive permission to set out on their voyages. There was also another major difference. Ship captains were not usually restricted as to the ships they could capture such as those of a particular nationality. Since Islamic warfare against Christians was deemed perpetual, they could attack whom they chose, unless a truce had been declared or a treaty was in effect. The unfortunate captives of such operations were not considered "prisoners of war;" rather they were enslaved. Depending on their wealth, social rank, or political importance, some might be well-treated but would not be released until ransomed by the ship owners or the nation of which they were subjects or citizens. If the captured seafarers were ordinary sailors or passengers, they were subjected to hard labour, imprisonment, harassment, and abuse, especially if they were Christians. Usually, the Islamic corsairs cruised singly and did not join in alliances with other regency corsairs. As Lincoln Paine has noted, "lack of coordination and shared purpose on the part of Muslim states underscores the fact that while it that is customary to think in terms

\footnotetext{
${ }^{4}$ Alan G. Jamieson, Lords of the Sea: A History of the Barbary Corsairs, (London: Reaktion Books, 2012), 150-151; Marco Gemignani, "Mediterranean Sea: An Overview," OEMH, 2: $532-$ 535 .
} 
of a Mediterranean divided into Christian and Muslim spheres of influence, power among the littoral states split along innumerable secular and religious fault lines."

Among the eyewitness accounts of Algerine seafarers, we have James Cathcart who spent eleven years as a prisoner in Algiers. Cathcart had held a warrant as midshipman on the Continental frigate Confederacy during the American Revolution. In 1785 he was working a passage in the merchant ship Maria heading from Boston to the Mediterranean when his ship was stopped by an Algerian xebec as they were nearing the Strait of Gibraltar. He and all his shipmates were made slaves and ordered to join hundreds of others, who were invariably Christians, to do all the hard physical labor required in the port. He was in a good position to observe how the slaves rigged, repaired, and made the corsairs' cruisers ready for sea. The captains and other officers of these vessels were often Turks, Moors, or renegade Christian sea captains who had "turned Turk." Aside from the few able Algerine seamen, the crew was made up of ordinary townsmen, "inferior Moors or Country Arabs," who had other trades when not at sea. When cruisers were about to depart these men were rounded up and forcibly driven to the waterfront with nothing but the clothes on their back. Although comprising the informal fighting force (marines) of the cruisers, they were not at all familiar with working the great guns. However, armed with attagans (swords) and other edged weapons, combined with their native hostility toward Christians, they were a formidable force when boarding an enemy ship. As Cathcart put it, "as an enemy they ought not to be undervalued."

In 1784, the emperor of Morocco ordered the American merchant ship Betsey to be detained and held hostage until the conclusion of a treaty of friendship and commerce. In May of that year the US established a commission to negotiate treaties of amity and commerce with Morocco, Algiers, Tunis, and Tripoli. At that time, John Jay had become secretary of state for foreign relations of the United States. John Adams had been appointed minister to Great Britain and Thomas Jefferson had replaced Jay as minister to France. With the invaluable assistance of diplomatic agent Thomas Barclay, Commissioners Adams and Jefferson obtained a treaty with Morocco in 1787 in which the United States was not obliged to pay tribute. ${ }^{7}$ This was a unique accomplishment, considering other nations still yielded to this practice,

\footnotetext{
${ }^{5}$ Lincoln Paine, The Sea and Civilization: A Maritime History of the World (New York, NY: Alfred A. Knopf, 2013), 212-213.

${ }^{6}$ James Cathcart, The Captives: Eleven Years a Prisoner in Algiers (La Port, IN: Herald Print, 1899; reprinted, London, UK: Forgotten Books, Dalton House, 2015), 81-84.

7 Thomas Barclay arrived in the Moroccan capital of Marrakech in June 1786, after five months of overland travel and a sea voyage from Cadiz to the Moroccan port of Mogador. After two audiences with the sultan, the draft treaty he had brought from Paris was accepted with only minor changes. When the question of future presents or tribute was informally raised he made it clear that there could be no question of either, or he would have to leave without a treaty. The matter was dropped and Barclay obtained for America a rare treaty with a Barbary power without promise of tribute-large annual payments and/or delivery of military or other goods of value. The treaty was ratified by Congress in July 1787. See Ray W. Irwin, Diplomatic Relations of the United States with the Barbary Powers, 1776-1816 (Chapel Hill, NC: University of North Carolina Press, 1931), 30-36.
} 
but treaties remained to be established with Algiers, Tunis, and Tripoli. The emperor of Morocco's motive in agreeing to such an agreement can be ascribed to his dislike of the British and his admiration of the American republic for successfully fighting the British. His attitude, however, was not shared by the other North African rulers. These states had seized American ships in 1785 after Spain and Portugal had made peace with Algiers. The British consul encouraged the dey of Algiers to harass American shipping. Shortly thereafter, Portugal was again at war with Algiers and sent ships to suppress their cruisers. In June 1786, the queen of Portugal ordered her squadron cruising in the Strait of Gibraltar to protect US vessels as well as those of Portugal. ${ }^{8}$

The difference in cultures accounts for the many of the difficulties American diplomats confronted in creating agreements with the Barbary Coast regencies. The commissioners faced two critical issues: the Islamic concept of jihad, of permanent holy war against the infidel, and the regencies' claim that the Mediterranean was their territorial sea and that the had a right to exert control over it. In both cases a maritime war seemed inevitable unless the United States could meet the Islamists' terms of agreement. John Adams's negotiations with the Algerines led only to their unacceptable proposal that the United States pay 30,000 guineas for perpetual peace, or as James Field has stated, "term insurance at 12,500 per year." The American government under the Articles of Confederation was nearly bankrupt and could not afford to pay such tribute even if Congress had permitted it. The American commissioners had worked hard for little result and were of different minds in how to remedy the situation. Adams, who had helped to establish the Continental Navy, was disillusioned by the failure of his efforts and thought it unlikely the US would fight. He reluctantly came to the view that his government should pay the tribute and get on with the trade. When Adams had an interview with Sidi Hadji Abdul Rahman Adja, the Tripolitan ambassador to Great Britain, in February 1786, he asked Adja: why, if there had been no hostility, injury, insults or provocations, between the United States and the Barbary states, should they be considered at war? The ambassador answered that Turkey, Tunis, Tripoli, Algiers and Morocco were the sovereigns of the Mediterranean and that no other nation could navigate that sea without having a treaty, otherwise, a state of war existed. On a second occasion, Adams pointed out that the United States was in financial difficulties, having recently completed a long and difficult war and was in no condition to offer large payments for peace in the Mediterranean. The ambassador acknowledged that point but in effect said the United States should at least make an offer which could be considered. Adams then told Jay that the only possibility would be to request an additional loan from Holland. ${ }^{10}$

\footnotetext{
${ }^{8}$ Adams to Jay, 27 June 1786, in The Emerging Nation: A Documentary History of the Foreign Relations of the United States under the Articles of Confederation, 1780-1789, 3: 206-7.

9 James A. Field Jr., America and the Mediterranean World, 1776-1882 (Princeton, NJ: Princeton University Press, 1969), 34.

${ }^{10}$ Adams to John Jay, 17 and 20 February, 1786, The Emerging Nation: 3: 99-104.
} 
Interestingly, Jefferson was more stubborn and militant, advocating a more aggressive naval policy, though as president fifteen years later, he gained a reputation as an anti-navalist. In 1784 he wrote James Monroe "We ought to begin a naval power, if we mean to carry on our own commerce. Can we begin it on a more honorable occasion, or with a weaker foe? I am of opinion [Commodore John] Paul Jones with half a dozen frigates would totally destroy their commerce . . . by constant cruising and cutting them to pieces by piecemeal." usual, Jefferson also believed that another possible solution would be the establishment of an international naval force that would keep piracy suppressed by continually cruising the Mediterranean. This visionary thought, however, would not come to fruition. John Jay advised that such a measure was unwise and would subject the United States to embarrassment since the government lacked the revenue required to provide America's share of an allied naval presence. ${ }^{12}$ In dealing with Tripoli and Algiers, the American representatives were unable to equal the tributefree Moroccan treaty. The Tripolitan ambassador explained that his government's policy was "founded on the Laws of the Prophet, that it was written in the Koran that all Nations who should not have acknowledged their authority [in the Mediterranean] were sinners, that it was their right and duty to make war on them wherever they could be found and to make slaves of all they could take as Prisoners, and that every Musselman who should be slain in battle was sure to go to Paradise." $" 13$

Adams and Jefferson laboured in much fruitless negotiation because the US government, under the Articles of Confederation, was unable to raise the money needed to insure the agreements. But it is interesting that the Tripolitans, while intent on fighting to protect their culture, were notably pragmatic in their application of warfare against infidels. An equitable treaty combined with the right price would end the fighting and the capturing of ships and crews, and indeed could lead eventually to trade. ${ }^{14}$ Writing to Jefferson, Adams fulminated, "the policy of Christendom has made cowards of all their sailors before the standard of Mahomet. It would be heroical and glorious in us to restore Courage in ours. ${ }^{15}$ Adams later despaired, saying that unless the United States could devise a better revenue system,

\footnotetext{
11 Thomas Jefferson to James Monroe, 11 Nov. 1784, as quoted in Dumas Malone, Jefferson and the Rights of Man (Boston: Little, Brown, 1951), 27-28.

12 John Jay's Report Opposing Formation of a Confederacy Against Algiers, Tripoli, and Tunis, 2 Aug. 1787 in The Emerging Nation, 3: 563-65.

13 Adams and Jefferson to John Jay, 28 March 1786, The Emerging Nation, 3:135-136. For a vivid autobiographical description of Algiers at this time by an American sailor, see Cathcart, The Captives: Eleven Years a Prisoner in Algiers.

${ }^{14}$ As Denise A. Spellberg, points out in Thomas Jefferson's Qu'ran: Islam and the Founders (NewYork, NY: Alfred Knopf, 2013), 146-148: "Sunni legal schools promoted the idea that peace, when in the interest of the Islamic community, was an acceptable alternative to war, even the variety of war known as jihad or struggle."

${ }^{15}$ Adams to Jefferson, 3 July 1786, The Emerging Nation, 3: 214-215.
} 
"your plan of fighting will be no more adopted than mine of negotiating." ${ }^{.16}$ From 1786 to 1789 , the US was unsuccessful in negotiating solutions to the hostility of Algiers and Tripoli. As a result, the United States came to consider the establishment of a naval force as a necessary step in the protection of its commerce in the Mediterranean.

With the inauguration of President George Washington, and the commencement of the new nation's foreign affairs, his administration sought aid in the courts of Europe in the hope of finding an ally whose diplomats and navy would protect American shipping in the Mediterranean. US Minister Thomas Jefferson, in France made vigorous protests and pleas, yet failed to enlist the needed support. Secretary of War Henry Knox opened the controversial subject of constructing a navy to punish the Barbary states for interdicting American trade and enslaving a people who had just fought a war in order to be free. Congress passage, in March1794, "An Act to Provide a Naval Armament" which called for the construction of six frigates which would soon become the core of the reinvented United States Navy, yet also required a halt of construction should a peace treaty with Algiers be approved. In the meantime, the first resort of the American government was to negotiate and offer ransom payments, an Old World custom that was at first considered a less expensive and less dangerous solution than the creating and maintaining of a fleet of warships.

For a brief time it was thought that a solution to the Algerine problem could still be found without resorting to force. Commodore John Paul Jones was residing in Paris and well-situated to represent American interests, but he was impoverished and in very poor health. Secretary of State Jefferson sent Jones a commission to act as envoy to Algiers, but he died before receiving the commission, which was passed to Thomas Barclay for implementation. Barclay also died soon thereafter, so the task to carry out the mission was given to David Humphreys, US minister to Portugal. As he was in midst of doing so, it was learned in Portugal that there had been a Portuguese - Algerine truce. This meant that the Portuguese would no longer suppress the Algerine raiders who would now be able to sail out of the Mediterranean into the Atlantic and that American ships were exposed to the Barbary corsairs on the high seas before entering the Mediterranean. The immediate result was a disaster for American shipping. Algerine corsairs seized eleven vessels in October and November 1792, and US maritime insurance rates for vessels sailing to the Mediterranean increased by 30 per cent.

The truce was an unpleasant surprise for the United States. During his tenure in London, John Adams had assiduously cultivated the Portuguese ambassador in an effort to obtain recognition and a treaty of friendship and commerce. Adams had received assurances that Portugal would protect American merchantmen as well. As evidence of her good will and desire for friendship, Queen Maria II sent a letter to Congress stating that as long as her warships cruised the in the mouth of the Strait

\footnotetext{
${ }^{16}$ Adams to Jefferson, 31 July 1786, The Emerging Nation, 3: 245; Irwin, Diplomatic Relations, 52.
} 
of Gibraltar they would protect American vessels as they would her own. ${ }^{17}$ In 1791, Portugal became the first neutral country to recognize the independence of the United States. Yet, three years later, with the Portuguese-Algerine truce, Portuguese warships could no longer provide this protection. How this came about has been the subject of much inquiry and debate.

At first, the Portuguese denied knowledge of the truce and claimed it was the brought about by the unauthorized interference by the British consul in Algiers, Charles Logie, who said he had negotiated the truce on behalf of the Portuguese government and at its request. Later it became apparent that decisions had been made in the highest echelons of the British government. Yet, Foreign Secretary Lord Grenville claimed the request had first come from the Portuguese court asking that Britain play an intermediary negotiating role because Portugal had need for its fleet to cooperate with the Britain, then at war with France. He had requested the British ambassador Robert Walpole to arrange this through their consul in Algiers. This is the way it worked out, but it is more likely the original impetus came from the British who had need of the Portuguese navy's ships to augment its own efforts to contain the French navy.

Still, the Portuguese court was angry because they had not had a chance to review the terms of Logie's truce agreement which had committed them to pay a large fee as compensation for the truce. The Portuguese refused to pay and rejected the agreement, whereupon the dey of Algiers wrote a heated letter of protest to King George III, alleging British had lured Algiers into the truce to take revenge on the Americans and that this would be more for Britain's benefit than for Algiers. ${ }^{18}$ Nathaniel Cutting, secretary to David Humphreys (US minister resident to Portugal), stated that Logie was hostile to Americans and overstepped his limits by personally issuing certificates of clearance to Algerian corsairs to attack American shipping. ${ }^{19}$ In any event, Portugal's removal of its warships from the Strait left the United States bereft of any means of protecting its merchantmen. This predicament led President Washington to authorize the building the first frigates of the US Navy. ${ }^{20}$

To renew negotiations with Hassan Bashaw, the dey of Algiers, the United States sent diplomatic agent Joseph Donaldson with instructions that he could offer as much as $\$ 800,000$ for peace and ransom. Assisted by the Swedish consul, a member of Bacri banking family, and James Cathcart, they reached an agreement after months of haggling. This treaty, signed in 1795 and ratified in 1797, originally called for payment of some $\$ 585,500$, and an annual gift $\$ 21,600$ or its equivalent

\footnotetext{
${ }^{17}$ Queen Maria I of Portugal to Congress, 2 August 1787, The Emerging Nation, 3: 565.

${ }^{18}$ Hassan Bashaw, dey of Algiers, to King George III, 27 March 1794; Richard B. Parker, Uncle Sam in Barbary: A Diplomatic History (Gainesville, FL: University Press of Florida, 2004), 231232.

${ }_{19}$ Ibid., 78-79; Irwin, Diplomatic Relations, 59-60.

${ }^{20}$ David Humphreys to George Washington, 31 January 1794, Founders Online, National Archives, last modified July 12, 2016; Irwin, Diplomatic Relations, 64-68.
} 
in naval stores. ${ }^{21}$ However, a two year delay in payments upset the arrangement. To assuage the dey's temper, in 1798 the US agreed to give a new completely outfitted 36-gun frigate named Crescent, plus a brig and two schooners, in exchange for the freedom of American seamen held in prison or bondage and continued forbearance on the part of Algerian corsairs. ${ }^{22}$ The total costs of the treaty including ransom, brokers' fees, gifts of ships, and remittance fees was estimated as high as $\$ 992,468$, well beyond originally claimed amount, so much so that the smaller European governments of Denmark and Sweden were alarmed that this would whet the appetites of Tunis and Tripoli. ${ }^{23}$ This was in fact a huge sum for its time, amounting to one eighth of the US government's budget, and indicating the importance that Americans laid on attaining a treaty. The United States halted construction on three of the six original frigates, but when hostilities with France broke out in the late 1790s, all were completed. Still, the United States sent no warships to the Mediterranean. This was justifiable, "on the ground that sound national policy calls for but one war at a time."24

The Tunis regency was next on the US diplomats' list. Discussions had been taking place since the middle 1790s with the first result being a six months' truce agreed to in June $1796 .{ }^{25}$ Conversations continued over the next three years led by David Humphreys and Joel Barlow (minister to Algiers). Finally, a treaty of friendship and trade was concluded on March 26, 1799, at an expense of $\$ 179,044$ to be paid by the United States and the first US consulate in Tunis opened its doors in January 1800.

\footnotetext{
${ }^{21}$ It may be of interest to note the style of the preamble of this treaty: "there have been negotiations for a treaty of peace between the ruler and commander of the American people, living in the island called America among the isles of the ocean, and the frontier post of the holy war, the garrison of Algiers."

${ }_{22}$ Avalon Project, Yale Law School, Documents in Law, History, and Diplomacy, 1786-1816; Treaty with Algeria, September 5, 1795, Hunter Miller's Notes; http://yale.law.edu., based on David Hunter Miller, Treaties and Other International Acts of the United States of America, 1931-48, 8 vols.; Howard I. Chapelle, The History of the American Sailing Navy (New York, NY: Bonanza Books, 1949), 135-140.

${ }^{23}$ Irwin, Diplomatic Relations, 78-81. This was a very large amount considering that the entire US budget was slightly over $\$ 8$ million, indicating the importance the American government placed on obtaining a peace settlement.

${ }^{24}$ Field, America and the Mediterranean World, 55-56.

${ }_{25}$ Avalon Project, Yale Law School, Documents in Law, History, and Diplomacy, 1786-1816: The Barbary Treaties 1786-1816; Tunis: Truce of June 17, 1796. Terms of the truce read as follows; "Now, until the answer comes and within a limit of six months after the date of this document, security has been given. Therefore, if during the said period war vessels of our well-preserved garrison place meet at sea with ships of the said Americans they shall not hinder them or molest them in any way, but they shall be treated as friends, and immediately order has been given to our officers to let them go their way. If American ships meet with ships belonging to our wellpreserved garrison place, it has been agreed between the two Governments, that they shall treat each other in a friendly way. This convention has been written and sealed and given into the hands of the said merchant, so that he may send it to its proper place. Until the arrival of the answer this convention shall be observed between the two Governments; according to it both parties shall act, and it shall be opposed in no way."
} 
Tripoli remained an obstacle. In the early 18th century, a Turkish janissary, Ahmed Karamanli overthrew the Turkish governor and persuaded the Ottomans to recognize him as governor. He established himself as bashaw, made his post hereditary, and thereby created the Karamanli dynasty which ruled Tripoli until the 1830s. Although he continued to pay nominal tribute to the Ottoman sultan, Karamanli otherwise acted as an independent ruler. He greatly expanded the regency's economy, particularly through the traditional employment of corsairs on crucial shipping routes. The region's delicate balance of power allowed the Karamanli family to survive several dynastic crises without invasion. In 1793, a civil war broke out during which an Ottoman officer, deposed Ahmed's grandson Hamet who had ruled since the overthrow of Ali I earlier that year. Two years later, Hamet returned to Tripoli with the aid of the bey of Tunis and took control of the throne but had ruled only five months when his brother Yussuf killed their father and another brother, deposed him, seized the throne, and sent Hamet into exile while keeping his wife and children as hostages.

Working to conclude a treaty with Tripoli at minimum cost, Humphreys and Barlow used the good offices of the dey of Algiers to draft a treaty with the Bashaw Yussuf over the years 1795-1797. This agreement provided peace with the United States with a one-time payment of $\$ 56,485$ for the treaty and the release of the captive American sailors, but no annual tribute. ${ }^{26}$ One of its provisions provided that should further negotiations prove necessary, the dey of Algiers would be available to mediate and that the first consul to be appointed by the United States would be obliged to bring an additional gift for the bashaw. ${ }^{27}$ James Cathcart, the first US consul appointed to Tripoli, reported to Secretary of State Timothy Pickering in 1798 that the bashaw had refused to accept his credentials. Yussuf was unhappy over the American delay in paying the treaty sum and other gifts. Then he also objected to the US using the dey of Algiers as a mediator because it made the bashaw look less important and threatened a return to hostilities. This led President Jefferson to consider a more forceful method of dealing with Tripoli.

At the close of the Quasi-War with France in 1800 the Jefferson administration ordered Commodore Richard Dale to prepare a squadron of four ships for a Mediterranean cruise to prevent the Barbary powers from "breaking the peace" and to ascertain the state of relations between these powers and the United States. If any or all had declared war against the United States, Dale was ordered to blockade their

\footnotetext{
${ }^{26}$ Joseph Wheelan, Jefferson's War: America's First War on Terror (New York, NY: Carroll \& Graf, 2003), 77.

${ }_{27}$ Avalon Project, Yale Law School, Documents in Law, History, and Diplomacy, 1786-1816; The Barbary Treaties 1786-1816: Treaty of Peace and Friendship, Signed at Tripoli November 4, 1796; Signed at Algiers 3 January 1797, ratified by the US on 10 June 1797. The consul's gift would include both cash and naval stores, to wit: "On the arrival of a consul of the United States in Tripoli he is to deliver to Yussuf Bashaw Bey - twelve thousand Spanish dollars, five hawsers-8 Inch, three cables-10 Inch, twenty five barrels tar, twenty five barrels pitch, ten barrels rosin, five hundred pine boards, five hundred oak knees, ten masts (without any measure mentioned, supposed for vessels from 2 to 300 ton), twelve yards, fifty bolts canvas, four anchors."
} 
ports and to "sink, burn or otherwise destroy their ships and vessels, wherever you find them. ${ }^{, 28}$ By the time Dale arrived in the Mediterranean, he discovered that the bashaw of Tripoli had already declared war against the United States

During the course of the first Tripolitan War, American squadrons in the Mediterranean were commanded successively by five commodores. Dale was succeeded by Commodore Richard Morris, whose inactivity dissatisfied Washington. Commodore Edward Preble provided bold leadership and applied all the pressure at his disposal against the recalcitrant bashaw. For assistance with diplomacy, Secretary of State James Madison had assigned Tobias Lear, a former consul to Santo Domingo, to work with Preble as consul general to the North African States. After Captain William Bainbridge's frigate Philadelphia ran aground in October 1803, it was Preble's decision to burn her while she was in enemy hands. Shortly afterward, Preble received news that the Tunisians were preparing to make war against American shipping because the United States had not paid the tribute it had promised. Preble's response was to call for reinforcements from the United States to continue operations against Tripoli and blockade Tunis at the same time. "These people," he wrote, "must not be humour'd but beaten." 29

The energetic Preble established valuable bases in the Mediterranean at Sicily and Venice, hired additional seamen, borrowed gunboats and bomb vessels manned by foreign crews, purchased supplies and naval stores, and rebuilt or refitted his ships. All of these improvisations were needed for successful naval actions far from the United States. These actions included blockades, shore bombardment and amphibious operations, enabling American officers to hone valuable fighting skills. In early September 1804, however, Preble was superseded by the more senior Commodore Samuel Barron. Arriving with Barron was William Eaton, the former American consul to Tunis. Eaton had obtained quiet approval from President Jefferson and his cabinet in March 1804 to develop a covert plan to force a victory. ${ }^{30}$ Eaton recruited handful of volunteers including a few US marines from the American squadron, a mixed force of European mercenaries found in Egypt, and Arab allies willing to fight under the banner of the bashaw's exiled brother Hamet. Before leaving the squadron, Commodore Preble had encouraged Eaton as well, providing him with letters of introduction to Sir Alexander Ball, British governor of Malta who in turn provided Eaton with letters of introduction to British representatives in Alexandria and Cairo.

The key to success would be to obtain the cooperation of the ousted Hamet, a former governor of Derne, who had fled to Egypt to escape from his brother's wrath.

\footnotetext{
${ }^{28}$ Acting Secretary of the Navy Samuel Smith to Captain Richard Dale, 20 May 1801, Knox, ed., Naval Documents related to the United States Wars with the Barbary Powers, 1: 465-69.

${ }^{29}$ Preble to J.M. Mathews, US Consul at Naples, 19 March 1804, Knox, ed. Naval Documents related to the US Wars with the Barbary Powers, 3: 506.

${ }^{30}$ American State Papers, Foreign Relations, 2: 701-02; Parker, Uncle Sam in Barbary, 146-47; William Eaton to Thomas Dwight, August 1804, in Charles Prentiss, ed., Life of the Late General Eaton (Brookfield, MA, 1813), 256-59.
} 
At the time Eaton sought out Hamet, he was about 150 miles south of Cairo fighting in a civil war ostensibly for the Turks against the Mamelukes. However, he had managed to change sides and had aligned with the Mamelukes. Eaton's daunting task was to find Hamet, convince him that the United States was seriously committed, and then to persuade the Turkish governor Achmed Bashaw Khorsid to let Hamet go. Eaton, who possessed a charismatic personality and a convincing military presence, charmed the bashaw and won over Hamet and his followers. They agreed on a rendezvous at Damonhur, an oasis south of Alexandria.

On 5 March 1805, this eclectic army set off on its march toward the coastal city of Derne, some 500 miles to the west. They gathered strength from tribes met along the way, finally numbering 600 to 700 fighters and 500 Arab and Bedouin camp followers. After many vicissitudes and several countermarches, Eaton gained the loyalty of his army long enough to arrive at the port of Bomba where Lieutenant Isaac Hull's USS Argus brought vitally needed provisions, military supplies and cash. From there, Eaton and Hamet led their followers to Derne which, again with Hull's help, they attacked, seized, and held against a cavalry force sent by Yussuf. The fact that Eaton's war party had so far succeeded had upset Yussuf's calculations and was costing him funds and loss of allies. Meanwhile, Samuel Barron's cruise as commodore was cut short by ill health, and he was replaced by Commodore John Rodgers. Eaton had planned to push on toward Tripoli but unbeknownst to him, Lear had made a breakthrough in negotiations on June 4. Several days later, USS Constellation arrived off Derna to make a midnight extraction of Eaton, his Marines, and Hamet and his retinue.

These events, combined with strengthened naval blockades and diplomacy, weakened the will of the bashaw. Consul General Lear's role came into play during Barron's illness. Never a supporter of Eaton's expedition, Lear was anxious to advance the pace of negotiations with Yussuf. The imprisoned Captain Bainbridge sent letters to Lear urging an early diplomatic settlement to forestall the bashaw's retributions against his prisoners for the Eaton-Hamet expedition's seizure of Derne. A peace treaty was finally agreed upon in June. The terms made no mention of future tribute payments, required the firing of gun salutes for American vessels, yet required that the United States would pay a ransom of $\$ 60,000$ for the release of Bainbridge and his crew.

There is little question that Eaton's expedition to Derne created a threat which pushed Bashaw Yussef into major concessions he was reluctant to make. The naval blockading squadron under Barron and Rodgers threatened but did not attack Tripoli perhaps because of fears that the bashaw would execute American prisoners. Despite having these forces at his disposal, Lear yielded to the bashaw's passionate insistence on a final payment, but he was acting in accordance with his instructions which allowed him to pay up to $\$ 600$ per man freed. He was prepared to pay $\$ 180,000$ for 300 American sailors but ended by paying only $\$ 60,000$ or $\$ 200$ per man. This, by existing standards, was a very inexpensive bargain. But, the treaty was not the decisive victory it has often been made out to be. Indeed, it has been alleged that the United States "sold out" or betrayed Hamet Karamanli. Lear had agreed to 
a secret article demanded by Bashaw Yussef. It stipulated that Yussef would be allowed to retain Hamet's wife and children as hostages for four years, after which the family would be released on Hamet's giving proof of his peaceful disposition toward the bashaw. Lear never divulged this article to his superiors in Washington. Yet it was known to Nicholas Nissen, the Danish consul, who duly reported the fact to Copenhagen. With this agreement, Tripoli became less troublesome. Still, fully peaceful relations were not established until after the War of 1812 .

Not long after the treaty with Tripoli was signed, the bey of Tunis disturbed the situation by threatening to declare war against the United States. He claimed the United States had not returned two prizes that it had been agreed would be restored to him after the escort had been captured. Commodore Rodgers refused to return the vessels. On 1 August 1805, the US squadron anchored at Tunis, and Rodgers asked the bey his intentions, threatening to begin hostilities if he did not receive a reply in 36 hours. Ultimately, the bey yielded and accepted the alternative of sending an ambassador to the United States to resolve the problem peaceably. ${ }^{31}$

During the years 1807-1808, the squadron declined in strength as the vessels were needed in the United States. An increase in naval tensions between the United States and Great Britain occurred in June 1807, owing to the Chesapeake-Leopard Affair, with the result that nearly all American ships were recalled from Europe. The American presence in the Mediterranean was limited to occasional visits from US Navy ships on their homeward bound voyages from northern Europe. More difficulty arose with Algiers because the United States was late in producing the two years' supply of naval stores stipulated by the treaty. When envoy Lear offered cash instead, the dey refused it. He then sent out a warship and captured three American merchantmen, one of which later escaped. The American sailors had over-powered the prize crew and threw several Algerines overboard. When the dey found out three months later, he demanded $\$ 18,000$ compensation from Lear. At first protesting he lacked authority to this, Lear finally paid the money, under duress.

With the outbreak of the War of 1812, American trade in the Mediterranean diminished greatly. In early 1812, the British consul to Algiers arrived with a letter calculated to arouse the dey against the Americans. When the ship Alleghany anchored at Algiers with naval stores as part of the tribute payment arranged in 1795 , the dey rejected the shipment claiming they were inferior products, and demanded \$27,000 immediately on pain of imprisonment and bondage. Further, he demanded the departure of Lear, his family, and many Americans remaining in Algiers, and then effectually broke the peace treaty by sending out his corsairs against American shipping.

While the United States was fully involved in the War of 1812, nothing forceful could be done in the way of releasing sailors newly captured in the Mediterranean, as in the case of the brig Edwin on 25 August 1812. This incident was to prove the

\footnotetext{
${ }^{31}$ Gardner Allen, Our Navy and the Barbary Corsairs (Hamden, CT: Archon Books, 1965; reprint of the 1905 edition), 268-269.
} 
catalyst for a settling of accounts with Algiers and several other Barbary regencies once the War of 1812 came to an end. The master, first mate, and a passenger were not confined but the remaining crew of eight was enslaved. The Algerines had captured one additional American, James Pollard, while sailing as a passenger on a Spanish ship. He, too, received the treatment most captives suffered, forced to hard labour and living in miserable conditions. The plight of these twelve Americans prompted the Madison administration, despite the ongoing war with Great Britain, to make an unusual attempt to liberate them. Secretary of State James Monroe assigned Mordecai Moses Noah, a young American Jewish diplomat to the consulship at Tunis, but before taking up that post, he was ordered to use covertly a network of Mediterranean bankers to ransom the twelve Americans without letting it be known the US government was behind the scheme.

Instead of travelling to Algiers in a private capacity, Noah based himself in Gibraltar and commissioned Richard Keene, the US consul in Cadiz, to carry out this mission on his behalf, although this was the last thing Monroe and Madison had anticipated. Keene, armed with bills of exchange provided by Noah, sailed to Algiers only to find that his mission was well understood to be backed by the United States government. The dey of Algiers himself heard and informed the Spanish consul that he would not release the Americans, even if offered a million dollars. Yet, just as Noah's mission looked like a complete failure, more American sailors appeared in Algiers, one a deserter from a British frigate who had "turned Turk" and four French-speaking Americans who had deserted from a another British ship. Keene, assisted by the British consul, saw an opportunity to free at least some Americans, the two from the Edwin whom the dey was willing to release and the four who claimed to be native Louisianans. The dey, pleased that he no longer had to deal with the British demands for the deserter, still held the balance of Edwin's crew that he could use to extract ransom, tribute and naval stores from the United States at the close of the War of 1812, or so he thought. Mordecai Noah believed himself at least partially successful, although he had displeased Madison and Monroe by ignoring their instructions. ${ }^{32}$

In 1815, at the conclusion of the War of 1812, the United States was in a much stronger position to deal with the Barbary states, having built additional warships during the conflict, including several ships-of-the-line. After declaring war, the United States sent two squadrons, the first comprised of ten vessels, under the command of Commodore Stephen Decatur, Jr., who captured two Algerine vessels. With this as evidence of his available force and determination, Decatur sent envoy Nathaniel Shaler to open negotiations with the dey. He obtained an agreement that provided for release of American captives, payment of compensation for Edwin, restoration of American property, for treatment of captives in any future war as prisoners of war exempt from labour, not as slaves, and excluded any payment of tribute. Despite many objections, the dey finally signed the treaty. This was the

\footnotetext{
${ }^{32}$ Frederick C. Leiner, The End of Barbary Terror: America's 1815 War Against the Pirates of North Africa (New York, NY: Oxford University Press, 2006), 21-38.
} 
occasion when Decatur wrote to Secretary of the Navy Crowninshield saying the treaty was "dictated at the mouths of our cannon." But, he added his advice that "the presence of a respectable naval force in this sea will be the only certain guarantee for its observance." ${ }^{\prime 33}$

Commodore William Bainbridge arrived in the Mediterranean with his squadron to reinforce Decatur's gunboat diplomacy. Bainbridge's flagship, the 74-gun Independence, provided the first appearance of an American ship of the line in those waters. The showing of the flag by this second powerful American squadron in Algiers, Tripoli, and Tunis had a salutary effect because it had been rumored that the United States had agreed with Britain not to build ships of the size of Independence. When Bainbridge departed in October 1815, he left behind a small but capable squadron made up of the frigates United States and Constellation, and the sloops Erie and Ontario to protect American interests under Commodore John Shaw.

When Commodore Oliver H. Perry relieved Shaw in March 1816, he brought with him the ratified treaty with Algiers. ${ }^{34}$ There he found a British squadron under Admiral Lord Exmouth who was involved in negotiating the release of Christian slaves and for an agreement that in the future there would be no payment of ransom in exchange for prisoners, for "it was not to be endured that England should tolerate what America had resented and punished." ${ }^{.35}$ However, this meeting ended in a violent disagreement with the dey. Exmouth departed abruptly but returned later that year with a larger force and subjected the Algerines to a crushing bombardment before obtaining his objective.

In conclusion, the United States had learned much in the way of diplomacy and the art of naval warfare since 1783. US diplomats had to adjust to bargaining with the avaricious, mercurial and often hostile Islamic rulers. American naval officers had to confront clever maritime enemies whose primary tactics were those of boarding and hand-to-hand combat rather than stand-off gunnery duels. This clash of maritime cultures led to the resolution of a crisis of more than thirty years standing though a combination of military action and diplomacy. The US Navy's actions in the Mediterranean had shown the way for Old World naval powers in the use of "gunboat diplomacy" in dealing the Barbary States. Naturally, as the commercial presence of the United States in the Mediterranean spread, the need for

\footnotetext{
${ }^{33}$ Allen, Our Navy and the Barbary Corsairs, 288.

${ }^{34}$ Avalon Project, Yale Law School, Documents in Law, History, and Diplomacy, 1786-1816; The Barbary Treaties 1786-1816: Treaty of Peace Signed Algiers June 30 and July 3, 1815; ratified and proclaimed December 26, 1815; and Treaty of Peace and Amity, with Article Additional and Explanatory, signed at Algiers December 22 and 23, 1816. This later treaty was brought to Algiers by Commodore Isaac Chauncey, commander in chief of US naval forces in the Mediterranean and minister plenipotentiary, accompanied by William Shaler, consul, as an amendment to the 1815 Treaty, nullifying the most favoured nation clause which had been included as Article 18 in the previous treaty.

35 Irwin, Diplomatic Relations, 182-185; Leiner, End of Barbary Terror, 151-174; David C. Skaggs, Oliver Hazard Perry, Honor, Courage, and Patriotism in the Early US Navy (Annapolis: Naval Institute Press, 2006), 168-172.
} 
American naval diplomacy grew apace. For these reasons, the US Navy has maintained a squadron in the Mediterranean from that day until our own, and the origins of the squadron are to be found in the events deriving from the very founding of the United States as an independent nation and the nature of commercial and military rivalries among Mediterranean and European powers. 